\title{
Strategic goals for a sustainable space in Russian Arctic cities and towns
}

\author{
Lyudmila Babkina $^{1}$, Oksana Skotarenko ${ }^{2,3, *}$, and Mikhail Kozin ${ }^{4,5}$ \\ ${ }^{1}$ North-Western Institute of Management, Branch of the Russian Presidential Academy of National \\ Economy and Public Administration under the President of the Russian Federation, 57 Sredniy Pr., \\ Vasilievsky Island, 199178 Saint Petersburg, Russia \\ ${ }^{2}$ Murmansk Arctic State University, 57 Prospekt Lenina, 183034 Murmansk, Russia \\ ${ }^{3}$ Military Academy of Logistical Support named after General of the Army A. V. Khrulyov, 8 \\ Naberezhnaya Makarova, 199034, Saint Petersburg, Russia \\ ${ }^{4}$ Research Institute of the Federal Penitentiary Service of Russia, 15A Ul. Narvskaya, Bld. 1, 125130 \\ Moscow, Russia \\ ${ }^{5}$ Federal State Budget Educational Institution of Higher Education "Gzhel State University", 67, \\ Elektroizolyator, Ramensky Raion, 140155 Moscow Oblast, Russia
}

\begin{abstract}
The article contains a ranking method for a comparative analysis for its study objects: seven cities and towns in the Russian Federation Arctic zone, in their relation between in each other in each of the three years of the analysis. The positions were determined by 18 major indicators divided in two groups - social and economic - and comprising a general set of social, environmental, and economic indicators reflecting the degree of sustainable development in the Russian Federation Arctic Zone. The analysis results allowed us to identify an additive rank of a city or town for each of the two groups of indicators and its changes over the study time frame. All of the cities were put in one of the five socioeconomic development groups by comprehensive additive socioeconomic rank and calculated average rank. The differentiation of the cities and towns by groups helped identify the opportunities and areas of further step-by-step strategic development of the cities in order to raise the level of socioeconomic development and create a united sustainable space in the Russian Arctic.
\end{abstract}

\section{Introduction}

The state of and development opportunities in the Russian Arctic Zone has been on the agenda recently [1,2].

Among Russian authors who study the issues of developing methodological approaches to studying regional economies we can name A. G. Granberg, V. I. Suslov, S. A. Suspitsyn [3]; A. S. Novosyolov [4]; L. N. Babkina, O. V. Skotarenko [5,6], and Arctic areas in particular: I. M. Zaychenko, O. V. Kalinina, S. S. Gutman [7]; G. F. Romashkina, N. I. Didenko, D. F. Skripnuk [8] et al.

A considerable contribution to creating various theoretical models of regional economies was made by distinguished international scholars, such as D. Bell [9], H. Innis [10,11], C. Clarke [12], T. Munn [13], G. Myrdal [14], R. Solow [15], E. Heckscher [16], et 
al. The basics of the qualimetric approach to studying socioeconomic phenomena and processes were developed the Russian scholar G. G. Azgaldov [17].

In our view, creating a united and sustainable social, environmental, and economic space should be one of the main strategic goals for the Russian Arctic. A highly concentrated urban population is typical of the Russian Arctic Zone. Consequently, all of the production, economic, and utility activities that use natural resources and pollute the environment with atmospheric emissions and contaminate the water bodies also happen there. The Norilsk oil spill disaster of 29 May 2020 can serve as an example of that.

\section{Materials and methods}

The study is based on a systemic and comprehensive methodological approach and uses comparative analysis to assess the level of socioeconomic development of a city or a town as part of the social, environmental, and economic space of the Russian Arctic Zone.

An essential data sample for the comparative analysis of the cities and towns by socioeconomic level was taken from annual government statistical reports over three years and comprised eighteen specific and relative indicators. They were divided into two groups - social and economic - and selected to ensure a comprehensive comparison of major constituents of socioeconomic development, industry, and social infrastructure in the cities and towns.

For the purposes of comparative analysis, we have compiled a ranking of the cities and towns by 18 indicators, by two indicator groups, and by general level of socioeconomic development for each year of the time period in question.

The study is based on systemic, comprehensive, and qualimetric methodological approaches to assess the level of socioeconomic development in Arctic cities and towns. It is also based on financial and economic analysis methods and statistic probability and index methods of regional qualimetry.

\section{Results and discussion}

In order to identify the strategic areas for federal and municipal governance in the Russian Arctic aimed at a unified sustainable space in the area, we have analysed the current conditions and their changes over three years (Table 1).

Table 1. Ranking of socioeconomic development levels in Arctic cities and towns in 2015-2017*

\begin{tabular}{|c|c|c|c|c|c|c|c|c|c|}
\hline \multirow[b]{2}{*}{ Indicator } & \multicolumn{3}{|c|}{ Arkhangelsk } & \multicolumn{3}{|c|}{ Severodvinsk } & \multicolumn{3}{|c|}{ Murmansk } \\
\hline & $\stackrel{n}{\stackrel{\text { N }}{1}}$ & $\stackrel{\circ}{\stackrel{\sim}{)}}$ & 공 & $\frac{n}{\tilde{N}}$ & 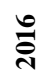 & 콩 & 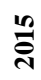 & 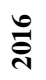 & 글 \\
\hline Social & 48 & 47 & 51 & 49 & 49 & 50 & 61 & 63 & 62 \\
\hline 1) Rate of natural increase per 1,000 people & 5 & 5 & 7 & 5 & 6 & 5 & 6 & 7 & 6 \\
\hline $\begin{array}{l}\text { 2) Average annual employment rate in the total } \\
\text { population, } \%\end{array}$ & 7 & 7 & 7 & 5 & 5 & 5 & 6 & 6 & 6 \\
\hline $\begin{array}{l}\text { 3) Registered unemployment rate in the total } \\
\text { population, \% }\end{array}$ & 2 & 3 & 4 & 1 & 2 & 2 & 5 & 6 & 6 \\
\hline 4) Average monthly nominal salary paid, RUB & 7 & 7 & 7 & 6 & 6 & 6 & 5 & 5 & 5 \\
\hline 5) Average monthly pensions paid, RUB. & 7 & 7 & 7 & 5 & 5 & 5 & 6 & 6 & 6 \\
\hline $\begin{array}{l}\text { 6) Newly-built residential houses, total area per } \\
\text { capita, sq. m }\end{array}$ & 3 & 3 & 3 & 4 & 4 & 4 & 5 & 5 & 5 \\
\hline $\begin{array}{l}\text { 7) Total average area of housing accommodation } \\
\text { per urban inhabitant, sq. } m\end{array}$ & 3 & 3 & 3 & 3 & 3 & 3 & 2 & 2 & 2 \\
\hline 8) Availability of preschool educational institutions & 3 & 3 & 3 & 1 & 1 & 1 & 6 & 6 & 6 \\
\hline 9) Number of physicians per 10,000 people & 3 & 2 & 3 & 6 & 5 & 7 & 4 & 3 & 4 \\
\hline
\end{tabular}


Continuation of Table 1. Ranking of socioeconomic development levels in Arctic cities and towns in 2015-2017

\begin{tabular}{|l|c|c|c|c|c|c|c|c|c|}
\hline 10) Number of nursing staff per 10,000 people & 3 & 2 & 2 & 4 & 4 & 3 & 5 & 6 & 4 \\
\hline 11) Number of hospital beds per 10,000 people & 4 & 4 & 4 & 6 & 6 & 6 & 5 & 5 & 5 \\
\hline $\begin{array}{l}\text { 12) Capacity of outpatient clinics per 10,000 } \\
\text { people, visits per shift }\end{array}$ & 1 & 1 & 1 & 3 & 2 & 3 & 6 & 6 & 7 \\
\hline \multicolumn{1}{|c|}{ Economic } & 21 & 21 & 25 & 30 & 29 & 29 & 16 & 16 & 15 \\
\hline $\begin{array}{l}\text { 13) Number of organisations and enterprises (state } \\
\text { registration data) per 1,000 people }\end{array}$ & 2 & 2 & 2 & 6 & 5 & 5 & 1 & 1 & 1 \\
\hline $\begin{array}{l}\text { Per capita volume of local goods produced and } \\
\text { services provided by activity, million RUB: }\end{array}$ & & & & & & & & & \\
\hline 14) minerals production & 3 & 2 & 4 & 7 & 7 & 7 & « & « & « \\
\hline 15) processing industries & 3 & 4 & 4 & 2 & 3 & 3 & 1 & 2 & 2 \\
\hline $\begin{array}{l}\text { 16) production and distribution of electricity, gas, } \\
\text { and water }\end{array}$ & 3 & 3 & 4 & 2 & 2 & 2 & 4 & 3 & 3 \\
\hline 17) Per capita retail turnover, RUB & 4 & 5 & 4 & 6 & 6 & 6 & 5 & 5 & 5 \\
\hline 18) Per capita capital investment, RUB & 6 & 7 & 7 & 7 & 6 & 6 & 5 & 5 & 4 \\
\hline Comprehensive assessment, points & 69 & 68 & 76 & 79 & 78 & 79 & 77 & 79 & 77 \\
\hline Average rank & 3.8 & 3.8 & 4.2 & 4.4 & 4.3 & 4.4 & 4.3 & 4.4 & 4.3 \\
\hline
\end{tabular}

Continuation of Table 1. Ranking of socioeconomic development levels in Arctic cities and towns in 2015-2017

\begin{tabular}{|c|c|c|c|c|c|c|c|c|c|c|c|c|}
\hline \multirow[b]{2}{*}{ Indicator } & \multicolumn{3}{|c|}{ Norilsk } & \multicolumn{3}{|c|}{ Naryan-Mar } & \multicolumn{3}{|c|}{ Anadyr } & \multicolumn{3}{|c|}{ Salekhard } \\
\hline & 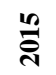 & $\stackrel{\text { กั }}{3}$ & 공 & 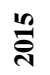 & $\stackrel{\text { กั }}{3}$ & 곻 & 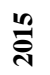 & 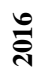 & 공 & 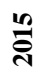 & 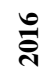 & ลิ \\
\hline Social & 48 & 45 & 46 & 46 & 44 & 46 & 28 & 28 & 27 & 34 & 30 & 31 \\
\hline $\begin{array}{l}\text { 1) Rate of natural increase per } \\
\text { 1,000 people }\end{array}$ & 2 & 2 & 3 & 3 & 3 & 2 & 4 & 4 & 4 & 1 & 1 & 1 \\
\hline $\begin{array}{l}\text { 2) Average annual employment } \\
\text { rate in the total population, } \%\end{array}$ & 4 & 4 & 4 & 2 & 2 & 2 & 1 & 1 & 1 & 3 & 3 & 3 \\
\hline $\begin{array}{l}\text { 3) Registered unemployment } \\
\text { rate in the total population, } \%\end{array}$ & 6 & 7 & 5 & 4 & 5 & 7 & 1 & 1 & 1 & 3 & 4 & 3 \\
\hline $\begin{array}{l}\text { 4) Average monthly nominal } \\
\text { salary paid, RUB }\end{array}$ & 3 & 3 & 3 & 4 & 4 & 4 & 1 & 1 & 1 & 2 & 2 & 2 \\
\hline $\begin{array}{l}\text { 5) Average monthly pensions } \\
\text { paid, RUB. }\end{array}$ & 2 & 2 & 2 & 3 & 3 & 3 & 1 & 1 & 1 & 4 & 4 & 4 \\
\hline $\begin{array}{l}\text { 6) Newly-built residential } \\
\text { houses, total area per capita, sq. } \\
\text { m }\end{array}$ & 5 & 5 & 5 & 2 & 1 & 1 & 4 & 4 & 4 & 1 & 2 & 2 \\
\hline $\begin{array}{l}\text { 7) Total average area of housing } \\
\text { accommodation per urban } \\
\text { inhabitant, sq. } m\end{array}$ & 1 & 1 & 1 & 2 & 2 & 2 & 5 & 4 & 4 & 4 & 1 & 1 \\
\hline $\begin{array}{l}\text { 8) Availability of preschool } \\
\text { educational institutions }\end{array}$ & 2 & 2 & 2 & 7 & 7 & 7 & 4 & 4 & 4 & 5 & 5 & 5 \\
\hline $\begin{array}{l}\text { 9) Number of physicians per } \\
10,000 \text { people }\end{array}$ & 7 & 6 & 6 & 5 & 4 & 5 & 1 & 1 & 1 & 2 & 1 & 2 \\
\hline $\begin{array}{l}\text { 10) Number of nursing staff per } \\
\text { 10,000 people }\end{array}$ & 5 & 3 & 4 & 6 & 6 & 5 & 2 & 4 & 2 & 1 & 1 & 1 \\
\hline $\begin{array}{l}\text { 11) Number of hospital beds per } \\
10,000 \text { people }\end{array}$ & 7 & 7 & 7 & 3 & 3 & 3 & 2 & 2 & 2 & 1 & 1 & 1 \\
\hline \begin{tabular}{|l|} 
12) Capacity of outpatient clinics \\
per 10,000 people, visits per shift
\end{tabular} & 4 & 3 & 4 & 5 & 4 & 5 & 2 & 1 & 2 & 7 & 5 & 6 \\
\hline Economic & 18 & 17 & 16 & 22 & 16 & 15 & 16 & 14 & 16 & 22 & 23 & 28 \\
\hline $\begin{array}{l}\text { 13) Number of organisations } \\
\text { and enterprises (state registration } \\
\text { data) per } 1,000 \text { people }\end{array}$ & 7 & 6 & 6 & 5 & 4 & 4 & 3 & 3 & 4 & 4 & 3 & 3 \\
\hline
\end{tabular}


Continuation of Table 1. Ranking of socioeconomic development levels in Arctic cities and towns in 2015-2017

\begin{tabular}{|c|c|c|c|c|c|c|c|c|c|c|c|c|}
\hline \multirow[b]{2}{*}{ Indicator } & \multicolumn{3}{|c|}{ Norilsk } & \multicolumn{3}{|c|}{ Naryan-Mar } & \multicolumn{3}{|c|}{ Anadyr } & \multicolumn{3}{|c|}{ Salekhard } \\
\hline & $\frac{10}{8}$ & 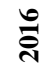 & ฮิ & $\stackrel{\text { ำ }}{\frac{\pi}{1}}$ & 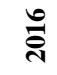 & ลิ & $\frac{\pi}{8}$ & 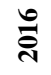 & $\overline{\bar{\lambda}}$ & $\frac{10}{8}$ & ำ & $\stackrel{4}{\overline{3}}$ \\
\hline $\begin{array}{l}\text { Per capita volume of local } \\
\text { goods produced and services } \\
\text { provided by activity, million } \\
\text { RUB: }\end{array}$ & & & & & & & & & & & & \\
\hline 1) minerals production & $\mathrm{x}$ & $\mathrm{x}$ & $\mathrm{x}$ & 2 & 2 & 2 & 1 & 1 & 1 & 2 & 3 & 3 \\
\hline 2) processing industries & $\mathrm{x}$ & $\mathrm{x}$ & $\mathrm{x}$ & 5 & 1 & 1 & 6 & 5 & 5 & 4 & 6 & 6 \\
\hline $\begin{array}{l}\text { 3) production and } \\
\text { distribution of electricity, } \\
\text { gas, and water }\end{array}$ & $\mathrm{x}$ & $\mathrm{x}$ & $\mathrm{x}$ & 6 & 5 & 5 & 1 & 1 & 1 & 5 & 4 & 6 \\
\hline $\begin{array}{l}\text { 4) Per capita retail turnover, } \\
\text { RUB }\end{array}$ & 7 & 7 & 7 & 3 & 3 & 2 & 2 & 2 & 3 & 5 & 4 & 5 \\
\hline $\begin{array}{l}\text { 5) Per capita capital } \\
\text { investment, RUB }\end{array}$ & 4 & 4 & 3 & 1 & 1 & 1 & 3 & 2 & 2 & 2 & 3 & 5 \\
\hline $\begin{array}{l}\text { Comprehensive assessment, } \\
\text { points }\end{array}$ & 66 & 62 & 62 & 68 & 60 & 61 & 44 & 42 & 43 & 56 & 53 & 59 \\
\hline Average rank & 3.7 & 3.4 & 3.4 & 3.8 & 3.3 & 3.4 & 2.4 & 2.3 & 2.4 & 3.1 & 2.9 & 3.3 \\
\hline
\end{tabular}

The study is focused on cities and towns in the Russian Arctic, including Anadyr, Arkhangelsk, Murmansk, Naryan-Mar, Norilsk, Salekhard, and Severodvinsk [18].

To carry out a comparative analysis of their social, environmental, and economic conditions, we used the data from the annual statistical reports [19] and a ranking method. The latter meant comparing the values of an indicator, such as a share of the whole (percentage), quantitative values per capita, 1,000, or 10,000 people, relative values, e.g. rate of change of the indicator compared with the previous or benchmark year (percentage, index), or comparing a process with the quantitative values of the same process in one or more territories in the respective year. The process having the highest quantitative value is assigned the first and the highest rank. The worst value corresponds to the lowest rank, which is the seventh here, corresponding to the number of the cities and towns. The number of the processes studied helped us obtain an additive (comprehensive) ranking for the respective year and use it to identify the territories having the best and, respectively, worst conditions. Comparing the additive ranks of each territory over the period of study - three years - helped us identify a positive or negative dynamic for the territory or stagnation of all of the processes. [5,6].

Out of the study objects, the most populous Arctic city was Arkhangelsk, with the average population of 358 thousand people in 2015-2017. The share of its population is $32 \%$ of the total population of the cities and town studied. It is followed by Murmansk, with the average population of 299 thousand people, which is 59 thousand below Arkhangelsk, and the corresponding 27\% share of the population.

Cities such as Severodvinsk and Norilsk take the 3rd and 4th place among the analysed Arctic cities, with their average population during the observed period from 2015 to 2017 being 187 and 176 thousand people, $17 \%$ and $16 \%$ of the total population, respectively. The average population of Salekhard is 48.5 thousand people. Its share of the population is slightly over $4 \%$. And, finally, the smallest towns are Naryan-Mar and Anadyr with their population of $24(2.2 \%)$ and 14.4 thousand people (1.3\%) respectively.

The comparative analysis of the socioeconomic conditions as the main constituent of sustainability of a city or town comprised 18 indicators [19]. The results of the analysis as a 
comprehensive assessment (additive rank) of the socioeconomic development level of cities and towns in the Arctic zone are shown in Table 1.

It should be noted that the biggest positive rate of natural increase is typical for small towns such as Salekhard, Naryan-Mar, and Norilsk (first rank). For instance, the maximum natural increase rate per 1,000 people in Salekhard in 2015-2017 was 11.3, 13.1, and 14.1 percentage points. In Naryan-Mar, the value of the indicator was 7, 8.1, and 10.5 percentage points, respectively. Finally, the natural increase rate in Norilsk was 9.3 pecentage points on average during the observed period. In Anadyr, the natural increase rate per 1,000 people in 2017 was just above 4, which is lower than in 2015-2016 with 2.2 percentage points on average. Arkhangelsk is characterised by a natural increase rate below 1 percentage points for all the three years analysed. A similar situation was observed in Severodvinsk and Murmansk in 2015 and 2017. In 2016, a decrease happened, equal to 0.5 and 0.3 percentage points respectively.

The highest annual average employment rate, equal to $65 \%$ of the total population, was observed in Anadyr, which determined the lowest unemployment rate during the whole period analysed, equal to $0.1 \%$ of the total population in 2017 . A decrease in this factor was registered compared to the previous years, which is a positive socioeconomic development trend

In the cities and towns of Naryan-Mar, Salekhard, Norilsk, the employment rate was $50 \%$ of the total population on average, which is $15 \%$ below Anadyr. In Naryan-Mar, the annual average recorded unemployment rate in the total population in 2015 was $0.56 \%$. Year 2016 showed a decrease to $0.44 \%$, and an increase occurred in 2017 resulting in the value of $0.97 \%$, which is almost 10 times more than in Anadyr. In Salekhard and Norilsk, the unemployment rates remained stable both in 2016 and 2017 , equal to $0.4 \%$ and $0.56 \%$ respectively.

About a third of the working-age population is employed by organisations in Severodvinsk, Murmansk, and Arkhangelsk, which is almost half of the Anadyr's figure and approximately half of that of Naryan-Mar, Salekhard, and Norilsk. Despite the low share of the employed, Severodvinsk officially recognises $0.29 \%$ of its total population as unemployed on average, which is the lowest value among the other cities and towns and corresponds to the 1st rank in 2015 and the 2nd rank in 2016-2017. In Arkhangelsk, during the whole period analysed, the rate of unemployment had increased from $0.3 \%$ in 2015 to $0.5 \%$ in 2017 . For instance, the highest percentage of the unemployed among all the Arctic cities and towns considered $-0.7 \%$ - was observed in Murmansk, which is 0.2 above the same value in Arkhangelsk, which had a very similar population and share of the employed.

The inhabitants of Anadyr had the highest average nominal monthly salary over the observed period, which was 81,533 RUB in 2015, 93,159 RUB in 2016, and 96,358 RUB in 2017. This indicator gets the first rank. The second rank by the indicator of average nominal monthly salary is held by Salekhard, where the employed people received 79,059 RUB in 2015, 82,616 RUB in 2016, and 83,032 RUB in 2017, which was lower than the Anadyr's average by $3 \%, 11.3 \%$, and $13.8 \%$ in the respective years.

The third rank is held by Norilsk where the average nominal monthly income was equal to 66,584 RUB, 70,798 RUB, and 76,466 RUB in 2015, 2016, and 2017, respectively. In comparison with Anadyr the respective average figure was lower by $18.3 \%$ in $2015,24 \%$ in 2016 , and $20.6 \%$ in 2017 .

In Naryan-Mar, the amount of nominal salary paid in 2015-2017 was lower by $6.5 \%$, $5.3 \%$, and $8.6 \%$ respectively in comparison with Norilsk and lower by $23.6 \%, 28 \%$, and $27.5 \%$ than in Anadyr over the same time period.

The lowest value of the indicator - 35,754 RUB in 2015, 38,289 RUB in 2016, and 40,303 RUB in 2017, which is considerably lower than in Anadyr (approximately 2.4 times lower) - was observed in Arkhangelsk that takes the lowest, $7^{\text {th }}$ rank. A similar situation 
was observed in Severodvinsk that takes the $6^{\text {th }}$ rank by the amount of average nominal monthly salary paid. The $5^{\text {th }}$ rank is held by Murmansk, where the indicator value was 46,351 RUB in 2015, 50,097 RUB in 2016, and 53,240 RUB in 2017, which is lower than in Anadyr by a factor of 1.8 on average.

Similarly to salary, the highest pensions were paid in Anadyr ( $1^{\text {st }}$ rank): 19,483 RUB in 2015, 21,189 RUB in 2016, and 23,364 RUB in 2017. The pensioners' income level is slightly lower in Naryan-Mar ( $2^{\text {nd }}$ rank) and Salekhard ( $3^{\text {rd }}$ rank). For instance, in 2017 the Naryan-Mar pensioners received 19,793 RUB on average, which is 1,290 RUB (or 7\%) higher than in Salekhard.

The Arkhangelsk pensioners have the lowest living standard ( $7^{\text {th }}$ rank), which is proven by their pension that was 12,801 RUB in $2015,13,886$ RUB in 2016 , and 15,446 RUB in 2017, which is lower by $34 \%$ compared to the Anadyr pensioners in 2015-2017. The income of pensioners in Murmansk and Severodvinsk is almost equal: the Severodvinsk pension was 16,867 RUB in 2017 compared to 16,593 RUB in Murmansk, making it 1.6\% relative difference. If we compare the pension in Anadyr, the highest in the Arctic zone, with those in Murmansk and Severodvinsk, the difference is almost 29\%.

By rate of new residential houses commissioning, Salekhard and Naryan-Mar were ahead of all the other cities and towns in the Arctic Zone, for instance, more than three times than in Arkhangelsk, almost 10 times than in Severodvinsk, and 30 times than in Murmansk! In 2015, Salekhard held the first rank, but the rate dropped in 2016-2017, and Salekhard made way for Naryan-Mar, where the per capita rate of residential construction was 1.02 and 0.89 sq. m, which was more than in Salekhard by 0.55 and 0.39 sq. $\mathrm{m}$ (or by a factor of 2 and 1.8). For comparison: in Arkhangelsk in 2015-2017, there was from 0.27 to 0.22 sq. $\mathrm{m}$ of new construction per capita. Extremely low figures approaching zero were typical for Severodvinsk, Murmansk, Norilsk, and Anadyr, just 0.01 to 0.1 sq. m.

The maximum per capita accommodation area -24.5 sq. $\mathrm{m}$ - was in Norilsk that held the first rank among all the cities and towns in the Arctic Zone. In the two following years, Salekhard also got the same rank, which is shown by the maximum per capita accommodation area of 25 and over 28 sq. m, respectively.

Over the whole observed period, the second rank was shared by Murmansk and NaryanMar, with the per capita accommodation area of 23 sq. $\mathrm{m}$ on average. The third rank was shared by Arkhangelsk and Severodvinsk, with the per capita accommodation area of 22.5 sq. $\mathrm{m}$ on average. Finally, the lowest number of sq. m per capita was in Anadyr, which holds the lowest, seventh rank.

The development level of social infrastructure is an important socioeconomic element. It is described by indicators, such as the availability of preschool educational institutions, number of physicians per 10,000 people, number of nursing staff per 10,000 people, number of hospital beds per 10,000 people, and capacity of outpatient clinics.

For instance, the overall level of availability of preschool educational institutions is between 0.35 to 1.05 in all the seven towns and cities. Norilsk and Severodvinsk have high values showing full availability of preschool institutions. In Arkhangelsk, Anadyr, and Salekhard, the values of the indicator over the whole analysed period were 0.97, 0.94, and 0.91 , corresponding to the third, fourth, and fifth ranks respectively. The lowest availability of preschool institutions $-65 \%$ and slightly over $50 \%-$ was observed in Murmansk $\left(6^{\text {th }}\right.$ rank) and Naryan-Mar ( $7^{\text {th }}$ rank).

Anadyr leads in the number of physicians per 10,000 people, with the number of 130 in 2015 and 94 and 93 in 2016 and 2017, respectively. Similar results were observed in Salekhard that holds the second rank. Severodvinsk and Norilsk $\left(7^{\text {th }}\right.$ and $6^{\text {th }}$ rank) were the most underperforming, with the value of this indicator being from 53 to 60 per 10,000 people. 
The highest availability of nursing staff was recorded in Salekhard, where there were 240 people of nursing staff on average per 10,000 people $\left(1^{\text {st }} \mathrm{rank}\right)$. A considerably lower availability, from 142 to 161 people, is typical for the other cities and towns.

The highest average number of hospital beds, equal to approximately 200 per 10,000 people, is typical for Salekhard, which holds the first rank. Similar results were registered in Anadyr and, slightly below, with about 170 beds, in Naryan-Mar. The seventh and last rank is held by Norilsk where the number of hospital beds per 10,000 people was about 80 .

The highest capacity of outpatient clinics in 2015-2017 was recorded in Arkhangelsk ( $1^{\text {st }}$ rank), with about 456 visits per shift per 10,000 people, the lowest capacity (nearly half of that of Arkhangelsk) being observed in Salekhard and Murmansk ( $6^{\text {th }}$ and $7^{\text {th }}$ rank).

The economic conditions in territories and the cities and towns located there are characterised by two types of indicators.

The former is calculated per 1,000 people: it is the number of enterprises and organisations.

The latter is calculated per capita and includes indicators, such as the volume of local goods produced and services provided by three activities: minerals production; processing industries; distribution of electricity, gas, and water; retail turnover; capital investment.

The first rank by number of enterprises and organisations (according to the state registration data) per 1,000 people is held by Murmansk, where the number rose from 50 to 53 over the three years. In Archangelsk, the indicator was average, equal to 36, 31\% below Murmansk, and corresponding to the second rank. In Salekhard, Anadyr, and Naryan-Mar, there were 30 enterprises and organisations per 1,000 people on average. Both in 20152016 and 2017, Severodvinsk held the penultimate position ( $6^{\text {th }}$ rank), and the number or enterprises and organisations per 1,000 people was 18 and 19, respectively. It is almost three times lower than the highest indicator value in the Arctic cities and towns in question. The last, $7^{\text {th }}$ rank of the indicator, equal to 13 , was held by Norilsk.

The largest volume of per capita minerals production in 2015-2017 - 3,275,041 RUB, 3,616,636 RUB, and 4,012,322 RUB respectively - was observed in Anadyr ( ${ }^{\text {st }}$ rank). The second rank was held by Naryan-Mar where the values were 2,537,113 RUB and 2,581,551 RUB, respectively, which is lower than the production volumes in Anadyr by a factor of 1.5 in 2015, 1.4 in 2016, and 1.6 in 2017. Norilsk and Murmansk could compete with them, but the data are not published in order to protect confidentiality of the information. Salekhard holds the third rank by that indicator among the Arctic cities and towns, and the minerals extraction is thousands of times lower there than in Anadyr. In Arkhangelsk, the specific value of this indicator dropped from 161.44 RUB to 96.01. There is no such activity in Severodvinsk, and it therefore holds the $7^{\text {th }}$ rank.

The largest per capita amount of goods produced, services provided, and work done by processing industries in 2015 was in Murmansk: 112,448 RUB ( $1^{\text {st }}$ rank), which is $46.7 \%$ more that in Severodvinsk, which holds the second rank, and 3.2 times more than in Arkhangelsk ( $3^{\text {rd }}$ rank). In 2016, the highest value of the indicator was observed in NaryanMar - 227,105 RUB ( ${ }^{\text {st }}$ rank) - 1.5 times higher than in Murmansk ( $2^{\text {nd }}$ rank). In 2017, Naryan-Mar kept its leading position. Moreover, the amount of goods produced by processing industries had increased by a factor of 2.2 and was 494,282 RUB per capita, which was 2.6 times more than in Murmansk, which held the second rank. The last place ( $7^{\text {th }}$ rank) was held by Salekhard, where the processing industries produced the equivalent of approximately 8,000 RUB per capita.

The highest figure in production and distribution of electricity, gas, and water in 20152017 was in Anadyr, where the per capita values were 118,443 RUB, 111,329 RUB, and 113,436 RUB, respectively ( $1^{\text {st }}$ rank). The second rank was held by Severodvinsk, where the indicator values were almost three times lower. Very similar results were recorded in Murmansk, Arkhangelsk, and Naryan-Mar, holding their respective $3^{\text {rd }}, 4^{\text {th }}$, and $5^{\text {th }}$ ranks. 
The lowest production and distribution of electricity, gas, and water in 2015-2017 was in Salekhard: slightly above 35,000 RUB on average ( $7^{\text {th }}$ rank).

The largest per capita retail turnover in 2015-2017 was registered in Murmansk: from 130.16 to 134.55 thousand RUB, respectively. In 2016, this figure had risen by $12.37 \%$ compared with the previous period and was 146.26 thousand RUB per capita. In 20152016, Anadyr considerably lagged behind the leading Murmansk: by $27.24 \%$ and $39.46 \%$ respectively, and in 2017, Naryan-Mar was $30.62 \%$ behind, holding the second rank. The lowest specific value, below 30 thousand RUB, was observed in Norilsk, which holds the seventh and last rank among the other Russian Arctic cities and towns.

By "per capita capital investment" indicator, Naryan-Mar held the first rank over the whole period of observation, with 1132.62, 1478.18, and 1522.25 thousand RUB respectively per capita, respectively. Salekhard, which held the second rank in 2015, was markedly behind by that indicator, with 553.63 thousand RUB of per capita capital investment, 51.11\% lower than in Naryan-Mar. In 2016-2017, the second rank was taken by Anadyr, where the figures for this indicator were 359.36 and 501 thousand RUB, $75.69 \%$ and $67.09 \%$ lower than in the leading town.

The lowest amount of capital investment in 2015 was 21.89 thousand RUB in Severodvinsk ( $7^{\text {th }}$ rank), which was 52 times lower than the maximum value in Naryan-Mar ( $1^{\text {st }}$ rank). In 2016-2017, the seventh and last rank was held by Arkhangelsk, which was evidenced by its per capita investment amount of 42.61 and 29.23 thousand RUB, 35 and 52 times lower than the respective values in Naryan-Mar in 2016-2017.

Thus, the comprehensive assessment of the socioeconomic development level of cities and towns in the Arctic zone (Table 1) has helped us calculate a summary rank for the cities and towns and divide them into five groups by rank calculated as an arithmetic mean value of the ranking values of the eighteen indicators.

Group 1 - high level of development (comprehensive assessment rank: 1 to 1.4 );

Group 2 - above-average level of development (comprehensive assessment rank: 1.52.8);

Group 3 - average level of development (comprehensive assessment rank: 2.9-4.3);

Group 4 - below-average level of development (comprehensive assessment rank: 4.45.7);

Group 5 - low level of development (comprehensive assessment rank: over 5.8).

For instance, Anadyr leads among the other cities and towns in the Russian Arctic in its socioeconomic development. It is evidenced by its average comprehensive rank, which was 2.4 in 2015 and 2017, corresponding to the second group with the above-average level of development (Table 1). In 2016, its average rank decreased by 0.1 to 2.3 , which showed a certain improvement in 2016. Therefore, a municipal system for management of socioeconomic processes as part of Anadyr's sustainable development should set is strategic goals for moving to the first, high-level group, prioritising economic improvement, since the social indicators are already better than in the other Russian Arctic cities and towns.

Over the whole period of observation, Norilsk, Naryan-Mar and Salekhard stayed in the third group with the average level of socioeconomic development. The comprehensive assessment rank stayed between 2.9 and 3.8. For this group, it is necessary to set mid-term strategic goals to move to the second group, achieving the indicator values currently shown by Anadyr. In the long run, the towns have to ensure the socioeconomic conditions to move to the first group.

Severodvinsk and Murmansk lagged behind the most in their socioeconomic development. From 2015 to 2017 , their average rank was 4.3 to 4.4 , placing them on the boundary between the third and the fourth group, i.e. between the average and belowaverage level of development. Those two cities have to set priority goals to stabilise their 
position in the third group and then raise their rating in the third group by implementing strategic social development goals.

The average rank of 3.8 in Arkhangelsk in 2015 and 2016 corresponded to the average level of socioeconomic development, placing the city in the third group. However, in 2017, the situation somewhat deteriorated, the rank dropped to 4.2, and the city approached the lower limit of the third group. Strategic goals for socioeconomic development of the three cities aimed at a united sustainable space in the Russian Arctic Zone should be set and implemented step by step. The first short-term step should aim at stabilising the socioeconomic level in the third group. The second mid-term step should aim at reaching the upper boundary of that third group. Then, in the long run, we recommend a transition from the third group to the second one, prioritising the social development goals.

The challenge of reaching the goal implementation criteria is that the quantitative socioeconomic indicator values in the cities and towns compared here are expected to change, most likely, upwards. The longer the time to reach the strategic goals, the more challenging it is to catch up with the leading cities and towns.

It should be noted that Table 1 lacks the required data that is not available in the government statistical reports. There is no data on the per capita volume of local goods produced and services provided by activities, such as minerals production, processing industries, on the production and distribution of electricity, gas, and water in Norilsk and minerals production in Murmansk. The indicators therefore had to be excluded from the comprehensive assessment. Availability of the statistical data for the comparative analysis would have added 1 rank to the existing position in the best result and 7 in the worst result. However, the final ranking would not have changed significantly, corresponding to the aforementioned socioeconomic development level of those cities and towns.

\section{Conclusions}

Cities and towns in the Russian Arctic Zone have different levels of socioeconomic development and do not constitute a single economic and social entity as part of a united social, environmental, and economic space. However, they have a great potential and should become centres of development in the Russian Arctic Zone as a whole. Therefore, to achieve a more uniform position of the cities and towns, it is required to establish and implement new strategic activities for socioeconomic and environmental development of the area and implement the existing national projects and plans in a timely and efficient manner.

Besides, the comparative analysis results show that, in order to build capacity of most of the Arctic cities and towns, it is necessary to develop the social infrastructure and expand and update the available housing. To eliminate the existing disproportion in the socioeconomic levels both within a city or town and between different Arctic cities and towns, a routine analysis of their development level should be carried out.

Results of such an analysis will help prioritise sectors and areas for improvement, provide a scientific background for strategic goals and socioeconomic development criteria aimed at covering the needs and raising the living standards of the people living in the Russian Arctic as a single, balanced, and unified social, environmental, and economic space.

\section{References}

1. On the principles of Russian Federation state policy in the Arctic up to 2035: Decree of the President of the Russian Federation, 05.03.2020, 164, Collected RF laws, 10, Art. 1317 (2020) 
2. On Approval of the Government Programme of the Russian Federation for Socioeconomic Development of the Arctic Zone of the Russian Federation: Decree of the Government of the RF, 21.04.2014, 366 (2014)

3. A. G. Granber, V. I. Suslov, S.A. Suspitsyn, Region: economics and sociology, 2 (2008)

4. A. S. Novosyolov, Novosibirsk IEOPP SO RAN, 18 (2008)

5. L. N. Babkina, O. V. Skotarenko, News of Science and Technology of the Saint Petersburg State Polytechnic University, 5 (2013)

6. O.V. Skotarenko. Vestnik MGTU, 1 (15) (2012)

7. I.M. Zaychenko, O.V. Kalinina, S.S. Gutman, Labor resources of the Far North territories: Problems and prospects, Proceedings of the 28th International Business Information Management Association Conference - Vision 2020: Innovation Management Development Sustainability and Competitive Economic Growth (2016), https://www.scopus.com/

8. G.F. Romashkina, N.I. Didenko, D.F. Skripnuk, Socioeconomic modernization of Russia and its Arctic regions Studies on Russian Economic Development, 28 (1), 22 (2017), https://www.scopus.com/

9. D. Bell, The cultural contradictions of capitalism (New York Basic books Cop XXXIV) (1978)

10. H. Innis Harold, The fur trade in Canada An introd. to Canad econ Rev ed (Toronto Buffalo Univ of Toronto press XX) (1977)

11. H. Innis, The idea file of Harold William Christian Toronto (etc Univ of Toronto press Cop XXI) (1980)

12. C. Clark, Bioeconomic modelling and fisheries management (New York etc.Wiley XII) (1985)

13. T. Mun, England's treasure by forraing trade (New York London Macmillan XVI) (1985)

14. G. Myrdal, Historien om an American dilemma (Stockholm SNS forl Cop) (1987)

15. R. Solow, Monopolistic competition and macroeconomic theory Cambridge (Cambridge univ press) (1999)

16. E. Heckscher, Nationalekonom och ekon historiker Texter $i$ urval av Rolf $G H$ Henriksson och Mats Lundahl (Stockholm Timbro Cop) (2003)

17. G. Azgaldov, Benchmark Int J, 3 (18) (2011)

18. On Land Territories in the Arctic Zone of the Russian Federation. Decree of the President of the Russian Federation, 02.05.2016, 296, Collected Laws, 18, Art. 2136 (2014)

19. Regions of Russia. Main Socioeconomic Indicators of Cities and Towns, Collected Statistics of Rosstat (2018) 